\title{
Biology Reproduction and Dynamic of Gonads Maturity Blue Swimming Crabs (Portunus pelagicus) in Betahwalang Waters, Demak
}

\author{
Sri Redjeki ${ }^{*}$, Muhammad Zainuri2, Ita Widowati ${ }^{1}$ Abdul Ghofar ${ }^{3}$, \\ Elsa Lusia Agus', Mustagpirin', Fabian Panji Ayodya'
}

\author{
Department of Marine Science, Faculty of Fishery and Marine Science, Diponegoro University \\ Department of Oceanography, Faculty of Fishery and Marine Science, Diponegoro University \\ Department of Aquatic Resources, Faculty of Fishery and Marine Science, Diponegoro University \\ JI. Prof Soedarto, SH., Tembalang, Semarang 50275 Indonesia \\ Email : sriredjekikelautan@gmail.com
}

\begin{abstract}
The waters of Betahwalang, Demak has quite potential fisheries resources. For the sustainability of crab resources, active management is necessary applied. Information on biology reproduction of crabs is required. The purpose of this research was to determine the biological aspects of sex ratio and the dynamics of the gonadal maturity level. This research was conducted on SeptemberNovember 2018 in Betahwalang Waters. The method used in this study is a descriptive research method. Data were collected by determining gender, weight and width of the carapace, the level of gonadal maturity. The results from observations of crab landed with a total of 6,292 crabs showed a percentage of $37.30 \%$ males and $62.70 \%$ females with sex ratios in September (1:1.70), October, (1: 1.46), and November (1:1.98). The observation of gonadal maturity level in September (Level I 162 crabs, Level II 1425 crabs, Level III 607 crabs) in October (Level I 130 crabs, Level II 832 crabs, Level III 207 crabs), and in November (Level I 46 crabs, Level II 753 crabs, Level III 195 crabs). The results show that the average crab catch on Betahwalang waters is dominated by the gonad II maturity level reaching (>70\%) of the total female caught. The results of the gonad maturity level are influenced by weather and season factors where the trend of the gonad maturity level will drop in the rainy season or in November.
\end{abstract}

Keywords: Rajungan; Biology Reproduction; Demak; Maturity Level; Sex Ratio

\section{INTRODUCTION}

Rajungan or Blue Swimming Crabs has high economic value and market demand both at domestic and abroad so that it becomes a valuable export commodity in fisheries. Exported small crab products in the form of frozen meat and small crab come mostly from small size crabs to egg crabs (Jacoeb et al., 2012). Starting from 2014 to 2016, the volume of small crab exports in Indonesia has increased with a value of 10.8 million tons to 19.4 million tons (APRI 2017).

High export demand encourages the exploitation of small crab resources from nature. Intensive exploitation and less selective resulting in disruption of the crab population balance in life, which will have an impact on the decline in crab stocks. Kurnia et al. (2014) from PGN bay that fisheries Labuhan Maringgai, Lampung Timur, said that Blue Swimming Crabs was caught over $100 \%$ and shows decrease population in nature. Small crab stock depends on several factors such as small crab that will spawn and low crab productivity associated with high intensity of exploitation (Lipcius and Stockhausen 2002).

Small crab resources in the waters of Betahwalang, Demak, Central Java have great potential, caused Betahwalang is one of the largest crab productions in Indonesia. Mostly Blue Swimming Crabs have a high price, demand, and was potential export in Indonesia. Although currently, there are zoning 
arrangements and time of capture to maintain crab productivity. A decrease in small crab productivity can occur if the high intensity of small crab exploitation in the coastal waters shallow to the middle sea waters. The crab was caught in Betahwalang in 2009 amounted to $40 \mathrm{~kg}$ in one sea trip. In 2014 the catch was getting lower at $7 \mathrm{~kg}$. The situation is exacerbated by the absence of data collection on crab catches so that the local government is difficult to determine policy. The small crab resources monitoring for the sustainability of fisheries is essential to maintain the stable low crab stock and catch the optimum (Istikasari et al., 2016). The purpose of this research is to find out the right period to be arranged for blue swimming crab catching through the gonad maturity information.

\section{MATERIAL AND METHODS}

The research material is 6,922 crabs (Portunus pelagicus) obtained by fishermen from Betahwalang waters, Demak. This research was conducted on SeptemberNovember 2018 in Betahwalang Waters. The method used in this research is descriptive research method. Data were Daily collected by determining gender, weight, and width of the carapace, the level of gonadal maturity. The gonads maturity level divided become three classes (level 1: Non-mature) (Level: 2 Mature) and (Level 3: maturated eggs) (APRI 2017; Prince 2017).

Analysis of the results of the data obtained was used descriptive analytic to see the relations between variables. The sex ratio aims to compare the number of male crabs with the number of female crabs from samples taken during the study. To analyse the number of male crabs and the number of female crabs is calculated (Effendie 2002). Reproductive biology was studied by examining the size at maturity. The characteristics of the level of gonad maturity refers to the Modification of Kunsook et al. (2014) and Prince (2017).

\section{RESULTS AND DISCUSION}

The results of this study, obtained blue swimming crab (Portunus pelagicus) with a total from observations of crab landed with a total of 6,292 crabs showed a percentage of $37.30 \%$ males and $62.70 \%$ females. The average carapace was $11,18 \mathrm{~cm}$, and the average weight was $94,60 \mathrm{~g}$. The most common male crab in September was 2194 crabs, and the least in November was 994 crabs. The highest number of female crabs was found in September, which was 1291 small crabs, while the least in November was 503 small crabs (Figure 1).

In September, male and female crabs were caught more frequently than in other months; this is presumably because, at the time of the study, the spawning season was occurring as in the statements of Romimohtarto and Juwana (2005). Besides, in September, there was a large number of arrests because many fishers conducted

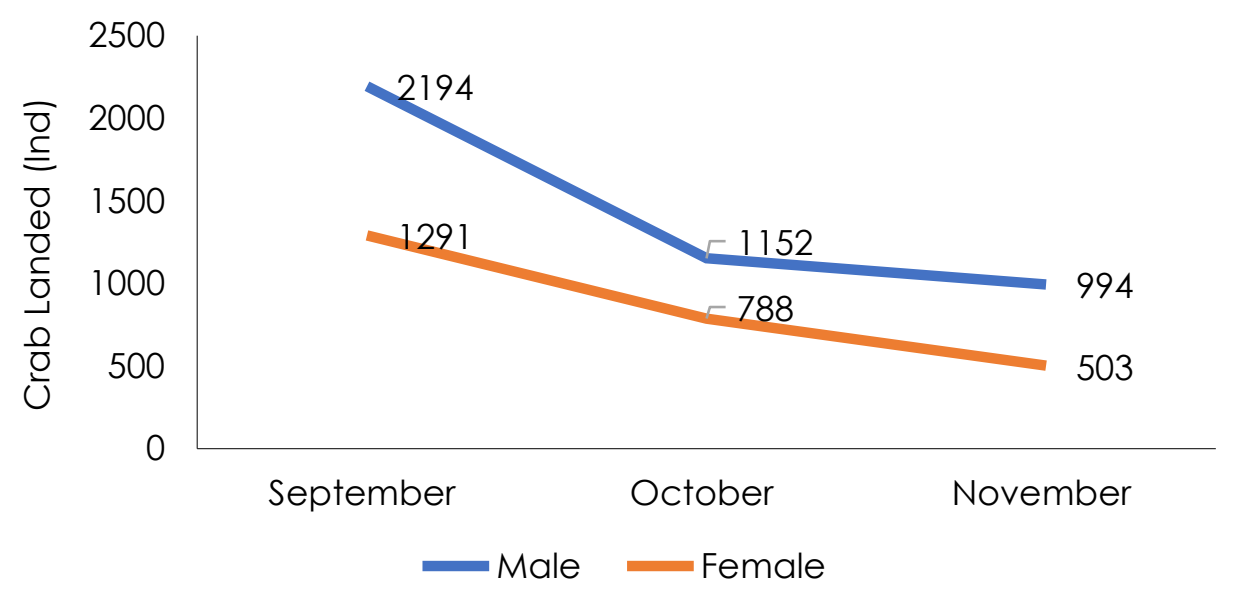

Figure 1. Number of male crabs and females are caught on each station in the Betahwalang waters, Demak 
fishing activities. In November and December, there were decreases in the name of arrests due to choppy season and made most of the fishermen in Betahwalang stop for catching crabs.

\section{Sex Ratio}

The results of the study were obtained females with sex ratios in September (1: 1.70), October, (1: 1.46), and November (1: 1.98) (Figure 2). The Ideal sex ratio between male and female are 1: 1, but this case different from conditions in nature that are not balanced. A comparison of the number of genders can predict success spawning, other than that can study population structure in nature to suspect the balance. Based on the results of the study obtained a ratio between male and small crabs females have a difference in ratio different, more in September male and female crab than November and December. It is suspected related to food availability and the life cycle of the small crab, especially in the reproductive period. According to Effendie (2002) comparison of sex ratio in nature will not absolutely be influenced by food availability, chain balance food, and population density. Male crab seems dominated the composition, this is same as research by Damora \& Erfind (2016) in Lampung waters. According to Potter \& Lastang (2000), female crab at certain time before spawning season doesn't settle in one area like the male crabs, this may cause the number female crabs catched less than the male ones.

The sex ratio in a population is influenced by seasonal conditions, migrations and weather (Hosseini et al., 2012). The imbalanced composition is caused by different habitat preferences. The female crab preference high salinity and deeper waters. The female changes behavior during the spawning season can reduce the potential for being catched by fisherman.

\section{The gonadal maturity level}

During the research in September December 2018, 2,582 female crabs and 4,340 males were found. The observation of gonadal maturity level in September (Level I 162 crabs, Level II 1425 crabs, Level III 607 crabs) in October (Level I 130 crabs, Level II 832 crabs, Level III 207 crabs), and in November (Level I 46 crabs, Level II 753 crabs, Level III 195 crabs) (Figure 3) and (Figure 4).

Based on research shows that swimming crab that was caught in September is the crab already matured. Mature gonads in large quantities. Whereas in October and November, the second-level gonads mature was dominated. As in the statement of

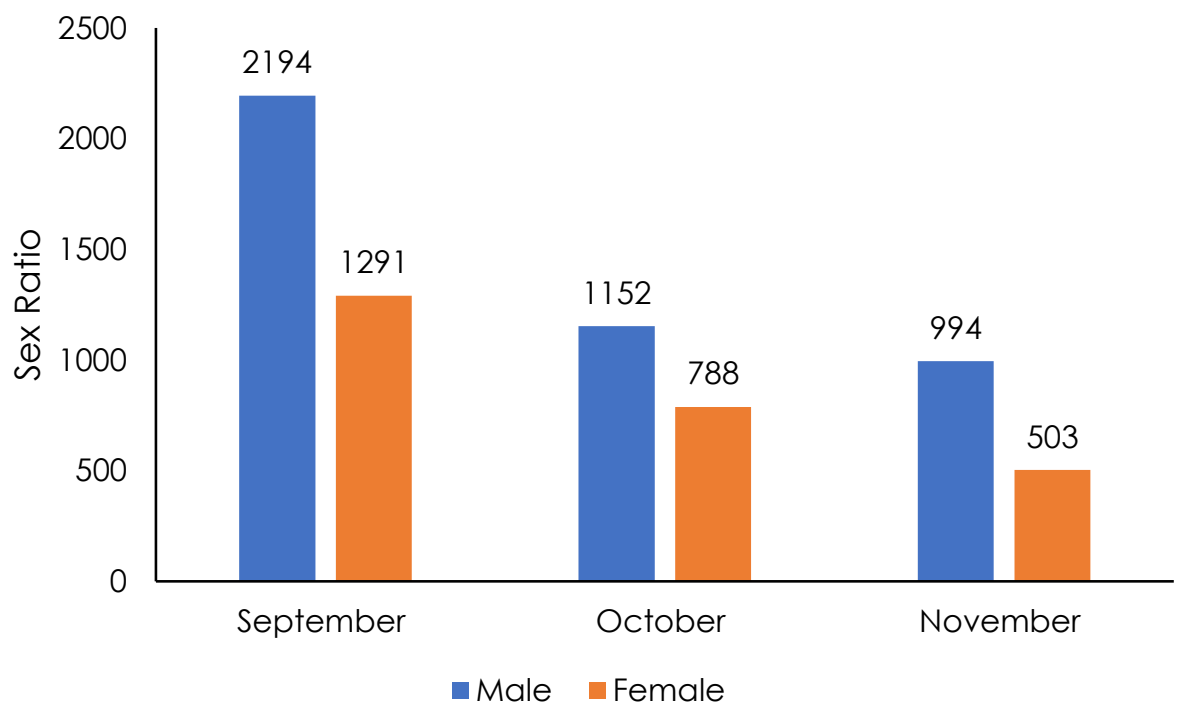

Figure 2. Male and female sex ratio caught in the Betahwalang waters 


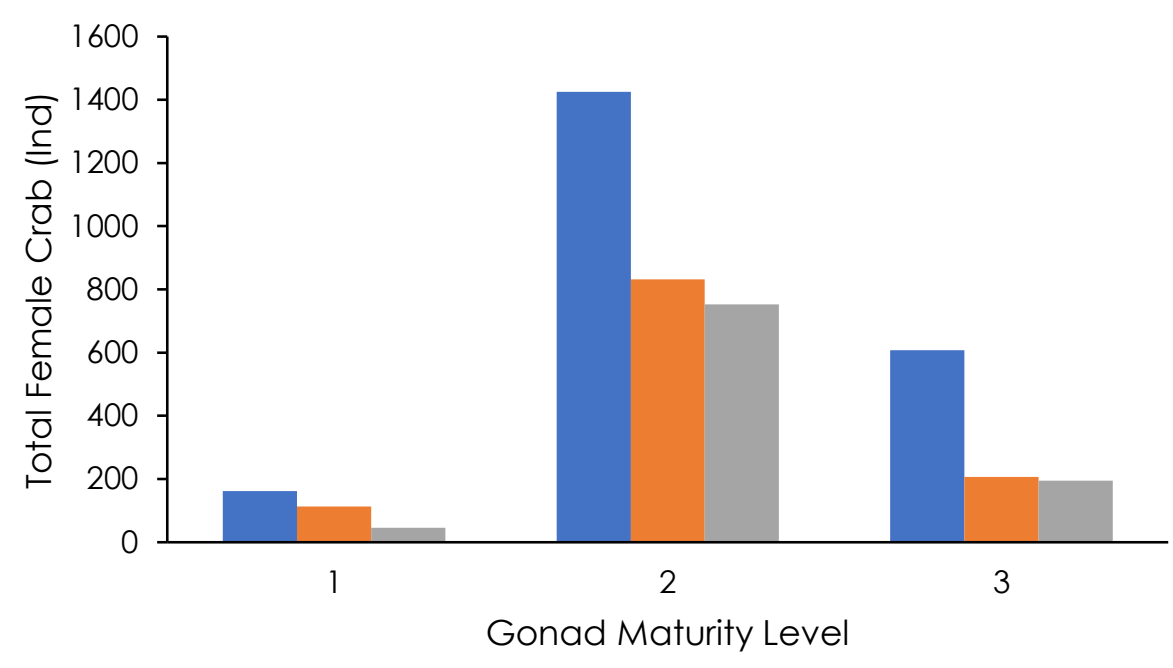

- September $\quad$ October $\quad$ November

Figure 3. Gonadal maturity level

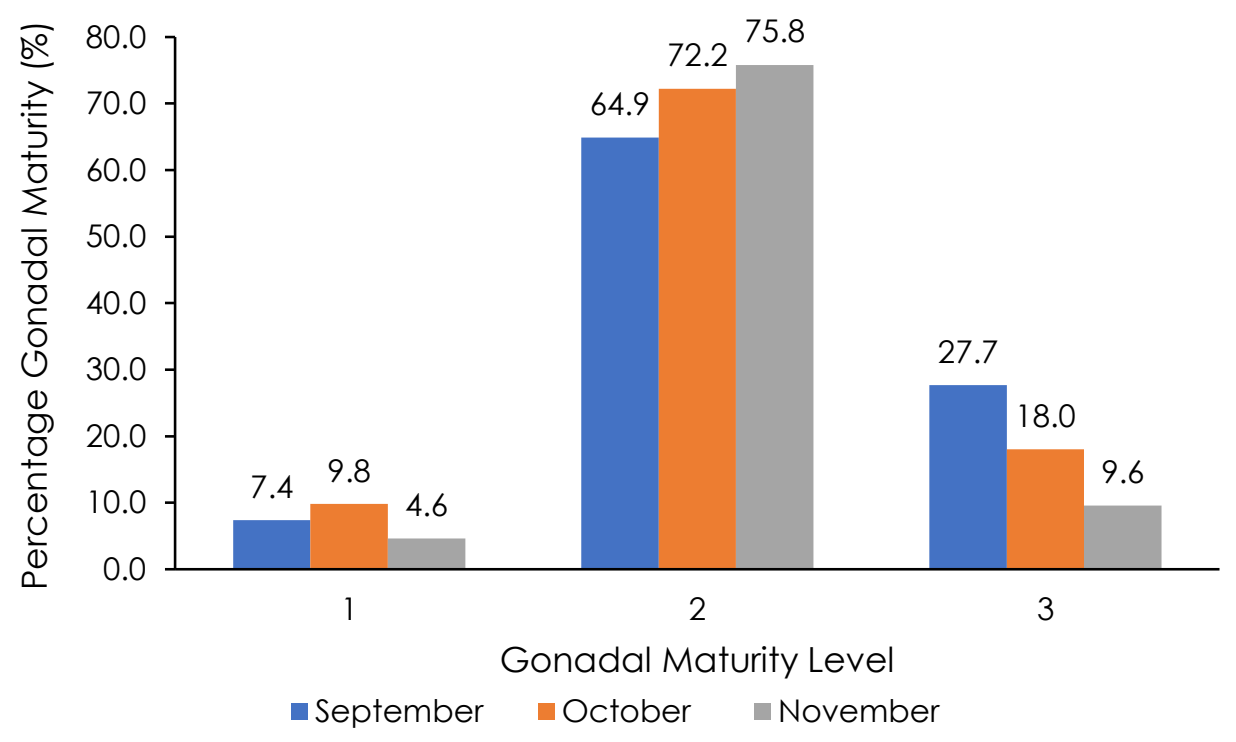

Figure 4. Percentage of Gonadal Maturity

Romimohtarto and Juwana (2005), that the crab spawning season occurs throughout the year with a peak occurring in the west season in December. The results show that the average crab catch on Betahwalang waters is dominated by the gonad II maturity level reaching (> 70\%) of the total female caught. The result indicated that fisheries' resources were being good in that location, causing the crabs were caught after releasing the eggs, but sometimes the fisherman still catching the crab with level 2 (mature) and level 3 (maturated eggs). The results of the gonad maturity level are influenced by weather and season factors where the trend of the gonad maturity level will drop in the rainy season or in November. These findings will provide information about knowledge about the development of blue swimming crab gonads and its population in nature to control the capture of this species in its habitat in the rainy season. 


\section{CONCLUSIONS}

The results from observations with sex ratios in September (1:1.70), October (1:1.46), and November (1:1.98). The observation of gonadal maturity level in September (Level I 162 crabs, Level II 1425 crabs, Level III 607 crabs) in October (Level I 130 crabs, Level II 832 crabs, Level III 207 crabs), and in November (Level I 46 crabs, Level II 753 crabs, Level III 195 crabs) and gonad II maturity level reaching (> $70 \%$ ) of the total female caught.

\section{REFERENCES}

Asosiasi Pengelolaan Rajungan Indonesia (APRI) Kab. Permalang, 2017 Pemalang Bertekad Pelihara Laut Pertahankan Kelestarian Rajungan. http://webcache. googleusercontent.com.

Damora, A. \& Erfind, N. 2016. Some Biological Aspek of Blue Swimming Crabs (Portunus pelagicus) in Maringgai Port, East Lampung. Bawal. 8(1):13-20.

Effendie MI., 2002. Fisheries Biology.. Yayasan Pustaka Nusatama. Yogyakarta. 163 pages. [in Indonesian]

Hosseini, M., Vazirizade, A., Parsa, Y. \& Mansori, A. 2012. Sex ratio, size distribution and seasonal abundance of blue swimming crab, Portunus pelagicus (Linnaeus, 1758) in Persian Gulf Coasts, Iran. World App. Sci. J. 17(7):919-925.

Istikasari I., Mudzakir, A.K. \& Wijayanto, D., 2016 [Crab Bioeconomic Analysis (Portunus Pelagicus) using Swept Area and Gordon Schaefer Approaches in Demak]. Prosiding Seminar Nasional. Fakultas Perikanan dan IImu Kelautan, Universitas Diponegoro. Semarang. 433-447.
Jacoeb, A.M., Nurjanah \& Lingga L.A.B., 2012 Characteristics of Protein and Amino Acid Crab Meat (Portunus pelagicus) Due to Steaming. J. Pengol. Hasil Perik. Ind. 2(15):156-163.

Rohmimohtarto, K. and Juwana, S., 2005. Biologi Laut IImu Pengetahuan Tentang Biota Laut Edisi ke Dua. Djambatan. Jakarta. $26 \mathrm{hlm}$

Kunsook, C., Nantana, G. \& Nittharatana P., 2014 A Stock Assessment of the Blue Swimming Crab Portunus pelagicus (Linnaeus, 1758) for Sustainable Management in Kung Krabaen Bay, Gulf of Thailand. Trop. Life Sci. Res., 25(1):41-59.

Kurnia, R. \& Boer, M., 2014. Biologi populasi rajungan (Portunus Pelagicus) dan karakteristik lingkungan habitat esensialnya sebagai upaya awal perlindungan di Lampung Timur. J. IImu Pertani. Indo., 19(1):22-28.

Lipcius, R.N. \& Stockhausen, W.T., 2002 Concurrent Decline of the Spawning Stock, Recruitment, Larval Abundance, and Size of the Blue Crab Callinectes sapidus in Chesapeake Bay. Mar. Ecol. Prog. Ser., 226:45-6.

Potter, I.C. \& de Lastang, S. 2000. Biology of the blue swimmer crab Portunus pelagicus (Linnaeus) (Decapoda: Brachyura) of the Madras Coast. Proc. Indian Acad. Sci. (B) 65:76-82.

Prince J.D., 2017 Informing community-based fisheries management with spawning potential surveys. SPC Fisheries Newsletter \#154. Pacific Community, Fisheries Information Section, BP D5, 98848 Noumea Cedex, New Caledonia

Rohmimohtarto, K. \& Juwana, S., 2005. Biologi Laut Ilmu Pengetahuan Tentang Biota Laut Edisi ke Dua. Djambatan. Jakarta. 